\title{
Endothelial progenitor cells in cardiovascular diseases: from biomarker to therapeutic agent
}

\author{
Hui-Bin Liu, Yuan-Feng Gong, Chang-Jiang Yu, Ying-Ying Sun, Xin-Yuan Li, Dan Zhao and Zhi-Ren Zhang*
}

\begin{abstract}
Regenerative medicine techniques to recover cardiac and vascular function are being increasingly investigated as management strategies for cardiovascular diseases. Circulating endothelial progenitor cells (EPCS) derived from bone marrow are immature cells capable of differentiating into mature endothelial cells and play a role in vascular reparative processes and neoangiogenesis. The potency of EPCs for cardiovascular regeneration has been demonstrated in many preclinical studies and therapeutic utility of EPCS has been evaluated in early-phase clinical trials. However, the regenerative activity and efficiency of the differentiation of EPCs are still limited, and a directed differentiation method for EPCs cells has not been fully demonstrated. In this review, we introduce the role of circulating EPCS as biomarkers of cardiovascular diseases and medical applications of EPCs for cardiovascular regeneration.
\end{abstract}

Keywords: Endothelial progenitor cells, Biomarkers, Cardiovascular regeneration

\section{Introduction}

Circulating endothelial progenitor cells (EPCs) are bone marrow derived peripheral blood mononuclear cells that have the capacity to proliferate, migrate, and differentiate into mature endothelial cells (ECs) [1]. EPCs were first discovered in human peripheral blood [2] and were shown to incorporate into sites of physiological or pathological neovascularization [3-5]. The discovery of EPCs has greatly enhanced our understanding of blood vessel formation. Accumulated evidence has elucidated that EPCs provide a postnatal vasculogenesis mechanism for neovascularization and vascular remodeling [6,7]. EPCs have a diverse of physiological functions and participate in the recovery processes of myocardial ischemia and infarction [8], limb ischemia [9], wound healing $[10,11]$, atherosclerosis [12], endogenous endothelial repair [13], and tumor vascularization [14]. Clinical trials have demonstrated that EPC therapy is safe and feasible for the treatment of cardiovascular diseases. In addition, circulating EPCs levels are considered as biomarkers for coronary and peripheral artery disease. However, despite significant steps toward defining their potential for both

\footnotetext{
*Correspondence: zhirenz@yahoo.com

Departments of Clinical Pharmacy and Cardiology, the 2nd Affiliated Hospital, Harbin Medical University, The Key Laboratory of Myocardial Ischemia, Chinese Ministry of Education, Harbin 150086, P.R. China
}

diagnostic and therapeutic purposes, further progress has been mired by unresolved questions regarding the definition and the mechanism of action of EPCs. This review will highlight the potential value of EPCs as the biomarkers and a potential therapeutic method for cardiovascular diseases.

\section{Review}

Endothelial progenitor cells (EPCs)

Adult bone marrow (BM) is a rich reservoir of tissuespecific stem and progenitor cells and EPCs constitutes 1-5 percent of the total bone marrow cells [15]. Based on the originated status, circulating EPCs can be subdivided into two main categories, hematopoietic lineage EPCs (HEPCs) and nonhematopoietic lineage EPCs (NHEPCs). The HEPCs originate from BM and identification of HEPCs is associated with the methods and markers of hematopoietic stem cells (HSCs) [16]. Nevertheless, it is still difficult to clearly distinguish between EPCs and HSCs for lacking of specific and selective markers for primary EPCs. The NHEPCs are isolated from blood or tissue samples but not BM cells, which can be successive cultured and distinguished by their rather obvious endothelial cell phenotype $[17,18]$. The origin of NHEPCs remains to be clarified, but they are generally thought to be derived from nonhematopoietic 
tissue-prone lineage stem cells or organ blood vessels but not like the HSCs [19]. EPCs are multiple cell types capable of differentiating into the endothelial lineage but not a single cell type [14]. The cells differentiated from EPCs possess the characteristic of mature ECs, including expressions of $\mathrm{CD}^{+} 1^{+}$, E-selectin ${ }^{+}$, endothelial nitric oxide synthase $(\mathrm{eNOS})^{+}$, and uptake of acetylated low density lipoprotein [20]. However, it is difficult to define EPCs precisely because of a lack of consensus regarding the best EPC source, the optimal isolation and culture techniques, and the phenotypes and characteristics that are especially crucial for EPC identity.

In 1997 Asahara and colleagues published a landmark paper in Science [2], showing that EPCs in adult human peripheral blood were CD $34^{+} /$VEGFR-2 $2^{+}$(vascular endothelial growth factor receptor 2) mononuclear cells. Subsequent studies confirmed that $\mathrm{CD} 4^{+}$cells from bone marrow or umbilical cord blood also had the capacity to differentiate into mature ECs in vitro and in vivo in mouse models $[4,21]$, thereby contributing to neoendothelialization and neovascularization in the adult organism. However, both CD34 and VEGFR-2 are expressed on mature ECs. Thus, better markers are needed. The stem cell marker CD133 (AC133) may be a more precise marker for defining EPCs, because CD133 is not expressed on mature endothelial cells [14]. However, CD133 expression declines as differentiation progresses, whereas CD34 expression is maintained, and the expression of endothelial markers (e.g., VEGF-2, von Willebrand factor [vWF], eNOS) increases [22]. Consequently, marker expression has been used to distinguish between early EPCs (e.g., $\mathrm{CD} 133^{+} / \mathrm{CD} 34^{+}$cells), early and late circulating EPCs (e.g., CD133/CD34 $4^{+}$cells), and EPCs that are nearing maturity (e.g., vWF ${ }^{+}$cells).

EPCs locating to damaged tissues and organs proceeding vascular regeneration do not only participate in the formation of the neovasculature but also produce a variety of proangiogenic cytokines and growth factors, promoting proliferation and migration of pre-existing ECs, activating angiogenesis to contribute to vascular regeneration [23,24]. This paracrine aspect of EPC activity was reflected by the presence of various cytokines and other secreting pro-angiogenic factors in EPCs such as VEGF, stroma derived factor (SDF)- $1 \alpha$, angiopoietin-1 (Ang-1), hepatic growth factor (HGF), insulin-like growth factor (IGF)-1, and eNOS/iNOS (inducible nitric oxide synthase) [25-27]. Therefore, EPCs can mediate tissue-protective effects and contribute to neovascularization via direct vasculogenesis in ischemic tissues and indirect production of proangiogenic factors to preexisting ECs.

\section{EPCs as potential biomarkers of cardiovascular diseases} Reduced numbers and impaired functionality of EPCs have been found in several clinical conditions such as diabetes mellitus [28,29], hypertension [30-32], heart failure [33] and chronic kidney disease [34-36]. It has been shown that the peripheral EPC number is reduced while EPC function is impaired and the numbers of circulating EPCs are significantly reduced in patients with established coronary artery disease [37] and stroke [38]. However, the number of EPCs is increased in patients with an acute coronary syndrome, such as acute myocardial infarction [39] or unstable angina [40,41], because they are mobilized from the bone marrow into the bloodstream. Importantly, the level of circulating CD $34^{+} /$VEGFR-2 $2^{+}$ EPCs further decline in the later stages of atherosclerosis in different districts, such as coronary [42-44], carotid and cerebral [45,46], and peripheral atherosclerosis [37,47]. Correlations were also found between severity of the atherosclerotic burden and EPC levels, $[38,46]$ indicating that low EPCs represent a biomarker of the systemic atherosclerotic involvement.

It has been shown that hypertension patients with coronary artery disease have reduced levels and migratory capacity of EPCs [48]. Moreover, the concentration of circulating EPCs is significantly reduced in refractory hypertension as compared to healthy subjects [49]. Imanishi et al. has reported that EPC senescence is accelerated in both experimental hypertensive rats and patients with essential hypertension, which may be related to telomerase inactivation $[32,50]$. They found the hypertension-induced EPC senescence might affect the process of vascular remodeling [50]. Thereafter, Delva et al. reported no alteration in the number or functional activity of EPCs in 36 patients with essential hypertension [51]. With regard to pulmonary hypertension, some studies have shown there is a decrease in the levels of EPC [52-54], while others report that normal levels of EPC or an increase in EPC number $[55,56]$. Therefore, at present, there is no evidence of a clear independent relationship between hypertension and the number of circulating EPCs [57].

Valgimigli et al. tested EPC levels in patients with heart failure (HF), and they found that EPC mobilization occurred in HF and showed a biphasic response, with elevation and depression in the early and advanced phases, respectively [58]. The increased EPCs had been shown as a reflection of a functional bone marrow response to diffuse and severe endothelial damage during the early stages of HF, but an additional and significant increase of tumor necrosis factor (TNF- $\alpha$ ) counteracted and overwhelmed the elevation of EPC mobilization in advanced disease phases by exerting a possible suppressive effect on hemopoiesis [59]. In contrast, another study showed that EPC levels were probably not influenced by the aetiology of HF, but rather correlated with the patient's clinical status [60]. A recent report has shown that HF patients with both preserved ejection fraction and reduced ejection fraction have significantly decreased circulating 
EPC levels, enhanced systemic inflammation, and higher $\mathrm{N}$-terminal pro-brain natriuretic peptide levels compared to controls [61].

Although the studies of EPCs as the biomarkers in cardiovascular diseases have not generated a conclusive result, these cells have widened the spectrum of cellular biomarkers and have supported the concept that circulating EPCs may affect the cardiovascular system.

\section{EPCs as a therapeutic agent}

Besides as potential cardiovascular risk biomarkers, EPCs have been extensively studied for their pathophysiological and therapeutic implications in cardiovascular diseases. However, several obstacles exist before large scale use of EPCs. For instance, the relatively rare cells must be expanded in sufficient numbers from peripheral blood, and possible changes in phenotype may increase the risk of cell senescence after in vitro enumeration of progenitor cells. Increasing the number and/or improving the function of EPCs may be promising in the treatment of atherosclerotic disease, ischemia or HF.

Myocardial ischemia caused by coronary artery disease can be attenuated by the development of collateral circulation; following the role of EPCs in neovascularization was recognized, investigators have begun to evaluate the potential therapeutic impact of EPCs. It has been shown that recovery of blood flow was greater in mice with hindlimb ischemia treated with EPCs than in control mice and in mice that received mature ECs, and that histological examinations confirmed EPC incorporation and differentiation into ECs [9]. Kawamoto and coworkers [8] evaluated EPC therapy in nude rats after acute myocardial infarction. These investigators found that intravenous administration of ex vivo expanded human EPCs could inhibit myocardial fibrosis and was able to preserve myocardial function. In addition, chronic treatment with bone marrow derived progenitor cells from young non-atherosclerotic apolipoprotein $\mathrm{E}$ knock-out $\left(\mathrm{ApoE}^{-/-}\right)$mice prevents atherosclerosis from progression in $\mathrm{ApoE}^{-1-}$ recipients [62]. In contrast, treatment with bone marrow cells from older $\mathrm{ApoE}^{-/-}$mice with atherosclerosis is much less effective. These results suggest that ApoE gene deficiency may not affect EPC repairing efficiency but that the chronic stimulation of EPCs in older $\mathrm{ApoE}^{-/-}$mice significantly weakens EPC repairing function. In addition, it has been demonstrated that EPC therapy improves regional systolic function accompanied by cardiac hypertrophy in porcine acute myocardial infarction models. The effect of EPCs on cardiac hypertrophy is mediated by paracrine secretion of cardiotrophic factors including TGF $\beta 1$ [63].

Several small-scale clinical trials have been performed to evaluate the use of bone marrow cell transplantation in treatment of cardiovascular diseases. However, the available clinical studies with respect to administration of circulating progenitor cells in cardiovascular diseases are mainly about $\mathrm{CD} 34^{+}$cells $[64,65]$; only a few studies suggest the role of $\mathrm{CD} 34^{+} / \mathrm{CD} 133^{+}$cells in cardiovascular diseases. Intracoronary infusion of $\mathrm{CD} 133^{+}$cells after acute myocardial infarction led to an improvement of left ventricular ejection fraction [66]. 167 patients with refractory angina received intramyocardial injections of mobilized, autologous $\mathrm{CD} 34^{+}$cells resulted in a significant improvement in angina frequency and a significant improvement in exercise response [64]. Another study suggests that injection of $\mathrm{CD}_{133^{+}}$cells into the myocardial border zone improves left ventricular function $[67,68]$. In patients with dilated cardiomyopathy, administration of autologously transplanted $\mathrm{CD} 34^{+}$cells led to an improvement of left ventricular ejection fraction [65]. Data collected from in vivo and in vitro experiments suggest that blockade of $\mathrm{C}-\mathrm{X}-\mathrm{C}$ chemokine receptor type 4 is sufficient to mobilize EPCs and to increase recruitment of EPCs to the neovasculature [69]. There is growing number of studies regarding EPC therapy in cardiovascular diseases, however, this therapeutic intervention in human remains to be further validated.

Although the preclinical and clinical studies reviewed here generally give strong support to the therapeutic potential of EPCs in the treatment of cardiovascular diseases, the clinical application of EPCs is limited by several factors. At first, the relatively shortage of circulating EPCs makes it difficulty to expand sufficient number of cells for therapeutic application without inducing the risk of cell senescence and change in phenotype $[2,70]$. Furthermore, the number and availability of EPCs are sensitive to some pathologic state, such as aging and diabetes which are always accompanied by cardiovascular diseases $[29,71,72]$, this severely restricts the ability of autologous EPCs to treat patients with cardiovascular diseases. Finally, for a successful therapeutic EPC-based approach, it is essential to get optimal quality/quantity of EPCs, such as ameliorating EPC purification and expansion methods, improving the administration and cellular application techniques, and recovering the disease-based dysfunction and/or senescence of patient-derived EPCs.

\section{Conclusions}

The involvement of EPCs in postnatal vasculogenesis and endothelial repair is supported by growing preclinical evidence. EPCs also participate in arteriogenesis in cardiovascular diseases. The mechanisms by which EPCmediated vessel growth and repair in cardiovascular diseases are not fully understood, the vasculogenic effects are thought to be attributed to the variety of angiogenic factors produced by EPCs. EPC-based therapy is still in very early stage, as critical questions regarding EPC survival, timing of administration, and phase- or activity- 
dependent efficacy of the diseases need to be addressed. The regenerative potency of EPCs will continuously be evaluated by ongoing, randomized, controlled clinical trials.

\section{Competing interests}

The authors declare that they have no competing interests.

\section{Authors' contribution}

HBL and YFG drafted the manuscript. ZRZ and HBL conceived and designed the study. CJY, and YYS helped to draft the manuscript. DZ and XYL revised the manuscript. All authors read and approved the final manuscript.

\section{Acknowledgement}

This study was supported by the Key Project of Chinese National Program for Fundamental Research and Development (973 Program, 2014CB542401), National Natural Science Foundation of China (81270340 and 81070217) and the Natural Science Foundation of Heilongjiang Province (ZD200807-01, ZD200807-02)

Received: 31 July 2013 Accepted: 16 October 2013

Published: 6 December 2013

\section{References}

1. Luttun A, Carmeliet G, Carmeliet P: Vascular progenitors: from biology to treatment. Trends Cardiovasc Med 2002, 12:88-96.

2. Asahara T, Murohara T, Sullivan A, Silver M, van der Zee R, Li T, Witzenbichler B, Schatteman G, Isner JM: Isolation of putative progenitor endothelial cells for angiogenesis. Science 1997, 275:964-967.

3. Iwaguro H, Yamaguchi J, Kalka C, Murasawa S, Masuda H, Hayashi S, Silver M, Li T, Isner JM, Asahara T: Endothelial progenitor cell vascular endothelial growth factor gene transfer for vascular regeneration. Circulation 2002, 105:732-738.

4. Shi Q, Rafii S, Wu MH, Wijelath ES, Yu C, Ishida A, Fujita Y, Kothari S, Mohle R, Sauvage LR, Moore MA, Storb RF, Hammond WP: Evidence for circulating bone marrow-derived endothelial cells. Blood 1998, 92:362-367.

5. Asahara T, Masuda H, Takahashi T, Kalka C, Pastore C, Silver M, Kearne M, Magner M, Isner JM: Bone marrow origin of endothelial progenitor cells responsible for postnatal vasculogenesis in physiological and pathological neovascularization. Circ Res 1999, 85:221-228.

6. Nolan DJ, Ciarrocchi A, Mellick AS, Jaggi JS, Bambino K, Gupta S, Heikamp E, McDevitt MR, Scheinberg DA, Benezra R, Mittal V: Bone marrow-derived endothelial progenitor cells are a major determinant of nascent tumor neovascularization. Genes Dev 2007, 21:1546-1558.

7. Werner N, Junk S, Laufs U, Link A, Walenta K, Bohm M, Nickenig G Intravenous transfusion of endothelial progenitor cells reduces neointima formation after vascular injury. Circ Res 2003, 93:e17-e24.

8. Kawamoto A, Gwon HC, Iwaguro H, Yamaguchi II, Uchida S, Masuda H, Silver M, Ma H, Kearney M, Isner JM, Asahara T: Therapeutic potential of ex vivo expanded endothelial progenitor cells for myocardial ischemia. Circulation 2001, 103:634-637.

9. Kalka C, Masuda H, Takahashi T, Kalka-Moll WM, Silver M, Kearney M, Li T, Isner JM, Asahara T: Transplantation of ex vivo expanded endothelial progenitor cells for therapeutic neovascularization. Proc Natl Acad Sci USA 2000, 97:3422-3427.

10. Suh W, Kim KL, Kim JM, Shin IS, Lee YS, Lee JY, Jang HS, Lee JS, Byun J, Choi JH, Jeon ES, Kim DK: Transplantation of endothelial progenitor cells accelerates dermal wound healing with increased recruitment of monocytes/ macrophages and neovascularization. Stem Cells 2005, 23:1571-1578

11. Marrotte EJ, Chen DD, Hakim JS, Chen AF: Manganese superoxide dismutase expression in endothelial progenitor cells accelerates wound healing in diabetic mice. J Clin Invest 2010, 120:4207-4219.

12. Fadini GP, Agostini C, Sartore S, Avogaro A: Endothelial progenitor cells in the natural history of atherosclerosis. Atherosclerosis 2007, 194:46-54.

13. Schmidt-Lucke C, Rossig L, Fichtlscherer S, Vasa M, Britten M, Kamper U, Dimmeler S, Zeiher AM: Reduced number of circulating endothelial progenitor cells predicts future cardiovascular events: proof of concept for the clinical importance of endogenous vascular repair. Circulation 2005, 111:2981-2987.

14. Khakoo AY, Finkel T: Endothelial progenitor cells. Annu Rev Med 2005, 56:79-101.

15. Khan SS, Solomon MA, McCoy JP Jr: Detection of circulating endothelial cells and endothelial progenitor cells by flow cytometry. Cytometry B Clin Cytom 2005, 64:1-8.
16. Timmermans F, Plum J, Yoder MC, Ingram DA, Vandekerckhove B, Case J: Endothelial progenitor cells: identity defined? J Cell Mol Med 2009, 13:87-102.

17. Ingram DA, Caplice NM, Yoder MC: Unresolved questions, changing definitions, and novel paradigms for defining endothelial progenitor cells. Blood 2005, 106:1525-1531.

18. Aicher A, Rentsch M, Sasaki K, Ellwart JW, Fandrich F, Siebert R, Cooke JP, Dimmeler $\mathrm{S}$, Heeschen C: Nonbone marrow-derived circulating progenitor cells contribute to postnatal neovascularization following tissue ischemia. Circ Res 2007, 100:581-589.

19. Timmermans F, Van Hauwermeiren F, De Smedt M, Raedt R, Plasschaert F, De Buyzere ML, Gillebert TC, Plum J, Vandekerckhove B: Endothelial outgrowth cells are not derived from $\mathrm{CD} 133^{+}$cells or $\mathrm{CD} 45^{+}$ hematopoietic precursors. Arterioscler Thromb Vasc Biol 2007, 27:1572-1579.

20. Yang $X F$, Yin $Y$, Wang $H$ : Vascular inflammation and atherogenesis are activated via receptors for PAMPs and suppressed by reglulatory T cells. Drug Discov Today Ther Strateg 2008, 5:125-142.

21. Ingram DA, Mead LE, Tanaka H, Meade V, Fenoglio A, Mortell K, Pollok K, Ferkowicz MJ, Gilley D, Yoder MC: Identification of a novel hierarchy of endothelial progenitor cells using human peripheral and umbilical cord blood. Blood 2004, 104:2752-2760.

22. Urbich C, Dimmeler S: Endothelial progenitor cells: characterization and role in vascular biology. Circ Res 2004, 95:343-353.

23. Urbich C, Aicher A, Heeschen C, Dernbach E, Hofmann WK, Zeiher AM, Dimmeler S: Soluble factors released by endothelial progenitor cells promote migration of endothelial cells and cardiac resident progenitor cells. J Mol Cell Cardiol 2005, 39:733-742.

24. Dai Y, Ashraf M, Zuo S, Uemura R, Dai YS, Wang Y, Haider H, Li T, Xu M: Mobilized bone marrow progenitor cells serve as donors of cytoprotective genes for cardiac repair. J Mol Cell Cardiol 2008, 44:607-617.

25. Ii M, Nishimura H, Iwakura A, Wecker A, Eaton E, Asahara T, Losordo DW: Endothelial progenitor cells are rapidly recruited to myocardium and mediate protective effect of ischemic preconditioning via "imported" nitric oxide synthase activity. Circulation 2005, 111:1114-1120.

26. Jujo K, li M, Losordo DW: Endothelial progenitor cells in neovascularization of infarcted myocardium. J Mol Cell Cardiol 2008, 45:530-544.

27. Miyamoto Y, Suyama T, Yashita T, Akimaru H, Kurata H: Bone marrow subpopulations contain distinct types of endothelial progenitor cells and angiogenic cytokine-producing cells. J Mol Cell Cardiol 2007, 43:627-635.

28. Loomans CJ, de Koning EJ, Staal FJ, Rookmaaker MB, Verseyden C, de Boer HC, Verhaar MC, Braam B, Rabelink TJ, van Zonneveld AJ: Endothelial progenitor cell dysfunction: a novel concept in the pathogenesis of vascular complications of type 1 diabetes. Diabetes 2004, 53:195-199.

29. Tepper OM, Galiano RD, Capla JM, Kalka C, Gagne PJ, Jacobowitz GR, Levine JP, Gurtner GC: Human endothelial progenitor cells from type II diabetics exhibit impaired proliferation, adhesion, and incorporation into vascular structures. Circulation 2002, 106:2781-2786.

30. Pirro M, Schillaci G, Menecali C, Bagaglia F, Paltriccia R, Vaudo G, Mannarino $M R$, Mannarino $E$ : Reduced number of circulating endothelial progenitors and HOXA9 expression in CD34+ cells of hypertensive patients. $J$ Hypertens 2007, 25:2093-2099.

31. Umemura T, Soga J, Hidaka T, Takemoto H, Nakamura S, Jitsuiki D, Nishioka K, Goto C, Teragawa H, Yoshizumi M, Chayama K, Higashi Y: Aging and hypertension are independent risk factors for reduced number of circulating endothelial progenitor cells. Am J Hypertens 2008, 21:1203-1209.

32. Imanishi T, Kobayashi $\mathrm{K}$, Hano $\mathrm{T}$, Nishio I: Effect of estrogen on differentiation and senescence in endothelial progenitor cells derived from bone marrow in spontaneously hypertensive rats. Hypertens Res 2005, 28:763-772.

33. Andreou I, Tousoulis D, Tentolouris C, Antoniades C, Stefanadis C: Potential role of endothelial progenitor cells in the pathophysiology of heart failure: clinical implications and perspectives. Atherosclerosis 2006, 189:247-254.

34. Choi JH, Kim KL, Huh W, Kim B, Byun J, Suh W, Sung J, Jeon ES, Oh HY, Kim DK: Decreased number and impaired angiogenic function of endothelial progenitor cells in patients with chronic renal failure. Arterioscler Thromb Vasc Biol 2004, 24:1246-1252.

35. de Groot K, Bahlmann FH, Sowa J, Koenig J, Menne J, Haller H, Fliser D: Uremia causes endothelial progenitor cell deficiency. Kidney Int 2004, 66:641-646.

36. Lorenzen J, David S, Bahlmann FH, de Groot K, Bahlmann E, Kielstein JT, Haller H, Fliser D: Endothelial progenitor cells and cardiovascular events 
in patients with chronic kidney disease-a prospective follow-up study. PLoS One 2010, 5:e11477.

37. Werner N, Kosiol S, Schiegl T, Ahlers P, Walenta K, Link A, Bohm M, Nickenig G: Circulating endothelial progenitor cells and cardiovascular outcomes. N Engl J Med 2005, 353:999-1007.

38. Ghani U, Shuaib A, Salam A, Nasir A, Shuaib U, Jeerakathil T, Sher F, O'Rourke F, Nasser AM, Schwindt B, Todd K: Endothelial progenitor cells during cerebrovascular disease. Stroke 2005, 36:151-153.

39. Shintani S, Murohara T, Ikeda H, Ueno T, Honma T, Katoh A, Sasaki K, Shimada T, Oike Y, Imaizumi T: Mobilization of endothelial progenitor cells in patients with acute myocardial infarction. Circulation 2001, 103:2776-2779.

40. George J, Goldstein E, Abashidze S, Deutsch V, Shmilovich H, Finkelstein A, Herz I, Miller H, Keren G: Circulating endothelial progenitor cells in patients with unstable angina: association with systemic inflammation. Eur Heart J 2004, 25:1003-1008.

41. Guven H, Shepherd RM, Bach RG, Capoccia BJ, Link DC: The number of endothelial progenitor cell colonies in the blood is increased in patients with angiographically significant coronary artery disease. J Am Coll Cardiol 2006, 48:1579-1587.

42. Bielak LF, Horenstein RB, Ryan KA, Sheedy PF, Rumberger JA, Tanner K, Post W, Mitchell BD, Shuldiner AR, Peyser PA: Circulating CD34+ cell count is associated with extent of subclinical atherosclerosis in asymptomatic amish men, Independent of 10-year framingham risk. Clin Med Cardiol 2009, 3:53-60.

43. Kunz GA, Liang G, Cuculi F, Gregg D, Vata KC, Shaw LK, GoldschmidtClermont PJ, Dong C, Taylor DA, Peterson ED: Circulating endothelial progenitor cells predict coronary artery disease severity. Am Heart J 2006, 152:190-195.

44. Fadini GP, Losordo D, Dimmeler S: Critical reevaluation of endothelial progenitor cell phenotypes for therapeutic and diagnostic use. Circ Res 2012, 110:624-637.

45. Lau KK, Chan YH, Yiu KH, Li SW, Tam S, Lau CP, Kwong YL, Tse HF: Burden of carotid atherosclerosis in patients with stroke: relationships with circulating endothelial progenitor cells and hypertension. J Hum Hypertens 2007, 21:445-451.

46. Bogoslovsky T, Chaudhry A, Latour L, Maric D, Luby M, Spatz M, Frank J, Warach S: Endothelial progenitor cells correlate with lesion volume and growth in acute stroke. Neurology 2010, 75:2059-2062.

47. Xiao Q, Kiechl S, Patel S, Oberhollenzer F, Weger S, Mayr A, Metzler B, Reindl M, Hu Y, Willeit J, Xu Q: Endothelial progenitor cells, cardiovascular risk factors, cytokine levels and atherosclerosis-results from a large population-based study. PLoS One 2007, 2:e975

48. Vasa M, Fichtlscherer S, Aicher A, Adler K, Urbich C, Martin H, Zeiher AM, Dimmeler S: Number and migratory activity of circulating endothelial progenitor cells inversely correlate with risk factors for coronary artery disease. Circ Res 2001, 89:E1-E7.

49. Oliveras A, Soler MJ, Martinez-Estrada OM, Vazquez S, Marco-Feliu D, Vila JS, Vilaro S, Lloveras J: Endothelial progenitor cells are reduced in refractory hypertension. J Hum Hypertens 2008, 22:183-190.

50. Imanishi T, Moriwaki C, Hano T, Nishio I: Endothelial progenitor cell senescence is accelerated in both experimental hypertensive rats and patients with essential hypertension. J Hypertens 2005, 23:1831-1837.

51. Delva P, Degan M, Vallerio P, Arosio E, Minuz P, Amen G, Di Chio M, Lechi A: Endothelial progenitor cells in patients with essential hypertension. J Hypertens 2007, 25:127-132.

52. Diller GP, van Eijl S, Okonko DO, Howard LS, Ali O, Thum T, Wort SJ, Bedard E, Gibbs JS, Bauersachs J, Hobbs AJ, Wilkins MR, Gatzoulis MA, Wharton J: Circulating endothelial progenitor cells in patients with Eisenmenger syndrome and idiopathic pulmonary arterial hypertension. Circulation 2008, 117:3020-3030

53. Fadini GP, Schiavon M, Rea F, Avogaro A, Agostini C: Depletion of endothelia progenitor cells may link pulmonary fibrosis and pulmonary hypertension. Am J Respir Crit Care Med 2007, 176:724-725. author reply 725.

54. Junhui Z, Xingxiang W, Guosheng F, Yunpeng S, Furong Z, Junzhu C: Reduced number and activity of circulating endothelial progenitor cells in patients with idiopathic pulmonary arterial hypertension. Respir Med 2008, 102:1073-1079.

55. Toshner M, Voswinckel R, Southwood M, Al-Lamki R, Howard LS, Marchesan D, Yang J, Suntharalingam J, Soon E, Exley A, Stewart S, Hecker M, Zhu Z, Gehling U, Seeger W, Pepke-Zaba J, Morrell NW: Evidence of dysfunction of endothelial progenitors in pulmonary arterial hypertension. Am J Respir Crit Care Med 2009, 180:780-787.
56. Asosingh K, Aldred MA, Vasanji A, Drazba J, Sharp J, Farver C, Comhair SA, Xu W, Licina L, Huang L, Anand-Apte B, Yoder MC, Tuder RM, Erzurum SC: Circulating angiogenic precursors in idiopathic pulmonary arterial hypertension. Am J Pathol 2008, 172:615-627.

57. Boos CJ, Goon PK, Lip GY: Endothelial progenitor cells in the vascular pathophysiology of hypertension: arterial stiffness, ageing and more. J Hum Hypertens 2006, 20:475-477.

58. Valgimigli M, Rigolin GM, Fucili A, Porta MD, Soukhomovskaia O, Malagutti P, Bugli AM, Bragotti LZ, Francolini G, Mauro E, Castoldi G, Ferrari R: $\mathrm{CD} 34+$ and endothelial progenitor cells in patients with various degrees of congestive heart failure. Circulation 2004, 110:1209-1212.

59. Dufour C, Corcione A, Svahn J, Haupt R, Poggi V, Beka'ssy AN, Scime R, Pistorio A, Pistoia V: TNF-alpha and IFN-gamma are overexpressed in the bone marrow of Fanconi anemia patients and TNF-alpha suppresses erythropoiesis in vitro. Blood 2003, 102:2053-2059.

60. Michowitz Y, Goldstein E, Wexler D, Sheps D, Keren G, George J: Circulating endothelial progenitor cells and clinical outcome in patients with congestive heart failure. Heart 2007, 93:1046-1050.

61. $\mathrm{CHC}$ : Decreased circulating endothelial progenitor cell levels in patients with heart failure with preserved ejection fraction free. J Am Coll Cardiol 2012, 59:E963-E963.

62. Rauscher FM, Goldschmidt-Clermont PJ, Davis BH, Wang T, Gregg D, Ramaswami P, Pippen AM, Annex BH, Dong C, Taylor DA: Aging, progenitor cell exhaustion, and atherosclerosis. Circulation 2003, 108:457-463.

63. Doyle B, Sorajja P, Hynes B, Kumar AH, Araoz PA, Stalboerger PG, Miller D, Reed C, Schmeckpeper J, Wang S, Liu C, Terzic A, Kruger D, Riederer S, Caplice NM: Progenitor cell therapy in a porcine acute myocardial infarction model induces cardiac hypertrophy, mediated by paracrine secretion of cardiotrophic factors including TGFbeta1. Stem Cells Dev 2008, 17:941-951.

64. Losordo DW, Henry TD, Davidson C, Sup Lee J, Costa MA, Bass T, Mendelsohn F, Fortuin FD, Pepine CJ, Traverse JH, Amrani D, Ewenstein BM, Riedel N, Story K, Barker K, Povsic TJ, Harrington RA, Schatz RA: Intramyocardial, autologous CD34+ cell therapy for refractory angina. Circ Res 2010, 109:428-436

65. Vrtovec B, Poglajen G, Sever M, Lezaic L, Domanovic D, Cernelc P, Haddad $F$, Torre-Amione G: Effects of intracoronary stem cell transplantation in patients with dilated cardiomyopathy. J Card Fail 2010, 17:272-281.

66. Stamm C, Kleine HD, Westphal B, Petzsch M, Kittner C, Nienaber CA, Freund $M$, Steinhoff $G$ : CABG and bone marrow stem cell transplantation after myocardial infarction. Thorac Cardiovasc Surg 2004, 52:152-158.

67. Bartunek J, Vanderheyden M, Vandekerckhove B, Mansour S, De Bruyne B, De Bondt P, Van Haute I, Lootens N, Heyndrickx G, Wijns W: Intracoronary injection of CD133-positive enriched bone marrow progenitor cells promotes cardiac recovery after recent myocardial infarction: feasibility and safety. Circulation 2005, 112:1178-1183.

68. Vanderheyden M, Vercauteren S, Mansour S, Delrue L, Vandekerckhove B, Heyndrickx GR, Van Haute I, De Bruyne B, Timmermans F, Wijns W, Bartunek J: Time-dependent effects on coronary remodeling and epicardial conductance after intracoronary injection of enriched hematopoietic bone marrow stem cells in patients with previous myocardial infarction. Cell Transplant 2007, 16:919-925.

69. Jujo K, Hamada H, Iwakura A, Thorne T, Sekiguchi H, Clarke T, Ito A, Misener S, Tanaka T, Klyachko E, Kobayashi K, Tongers J, Roncalli J, Tsurumi Y, Hagiwara N, Losordo DW: CXCR4 blockade augments bone marrow progenitor cell recruitment to the neovasculature and reduces mortality after myocardial infarction. Proc Natl Acad Sci USA 2010, 107:11008-11013.

70. Jia L, Takahashi M, Yoshioka T, Morimoto H, Ise H, Ikeda U: Therapeutic potential of endothelial progenitor cells for cardiovascular diseases. Curr Vasc Pharmacol 2006, 4:59-65.

71. Hill JM, Zalos G, Halcox JP, Schenke WH, Waclawiw MA, Quyyumi AA, Finkel T: Circulating endothelial progenitor cells, vascular function, and cardiovascular risk. N Engl J Med 2003, 348:593-600.

72. Edelberg JM, Tang L, Hattori K, Lyden D, Rafii S: Young adult bone marrowderived endothelial precursor cells restore aging-impaired cardiac angiogenic function. Circ Res 2002, 90:E89-E93.

doi:10.1186/2050-490X-1-9

Cite this article as: Liu et al:: Endothelial progenitor cells in

cardiovascular diseases: from biomarker to therapeutic agent.

Regenerative Medicine Research 2013 1:9. 